\title{
Downstream Impacts of the Melamchi Inter-Basin Water Transfer Plan (MIWTP) Under Current and Future Climate Change Projections
}

Pabitra Gurung and Luna Bharati

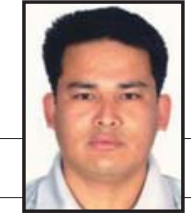

Pabitra Gurung

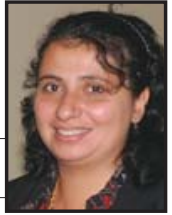

Luna Bharati

\begin{abstract}
The Melamchi Water Supply Project (MWSP) is designed to minimize the shortage of drinking water in the Kathmandu valley. Although the project was supposed to be completed by 2008 , due to various problems, it is still difficult to forecast the exact date of completion. This paper quantifies the downstream effects of diverting water from the Melamchi (Stage-I), Yangri (Stage-II) and Larke (Stage-III) rivers under current as well as future climate scenarios. The Soil Water Assessment Tool (SWAT) was used in the analysis. Result shows that in the Stage-I water transfer plan, average inflow reduction in the immediate downstream sub-basin in the dry and wet seasons are $36 \%$ and $7 \%$ respectively, where as in Stage-II the inflow reductions are 38\% for the dry season and $8 \%$ for the wet season. In Stage-III, inflow reductions are $38 \%$ in the dry season and $7 \%$ in the wet season.

The impact of the water transfer schemes on various changes in water management within the Melamchi River irrigation command area was also tested. BUDGET (soil, water and salt balance) model was used to quantify crop water requirement of Melamchi River command area when the irrigated area is increased and the cropping pattern is changed. Simulation results of crop water requirement in intensive water use conditions show that present Melamchi River command area can be increased by 2.2 times under current climate projection, whereas the area can be increased 1.4 times in 2030 s and by 2.0 times in 2050 s.
\end{abstract}

Key words: Inter-basin water transfer, climate change, SWAT, BUDGET, Koshi basin, Melamchi, Nepal

\section{Introduction}

Tn Nepal, as elsewhere, migration trends from rural to urban areas are growing. As a result, the population of urban centers, especially Kathmandu is increasing at a rapid rate. Meeting water demands in Kathmandu is therefore a major challenge for the government. There are nearly 2.2 million people living in the Kathmandu valley and their daily drinking water demand is about 220 million liters (MWSDB 2008). Recent project document has reported that their daily demand is 330 million liters. National Population Census (CBS 2011) reported that the population of Kathmandu valley is nearly 3.5 million including floating population. Daily available water, however, within Kathmandu valley is about 90 million liters in the dry season and 130 million liters in the wet season (MWSDB 2008). Hence, the Government of Nepal (GON), the donor community and Non-governmental organizations are involved in finding alternative water sources to tackle the water scarcity crisis in Kathmandu. The Melamchi Water Supply Project (MWSP) was identified as a potential solution in 1973. The GON started the implementation of the Melamchi Water Supply Project in 1998 and originally, expected the project to be completed by 2008. However, due to various problems including the issue of downstream hydrological impacts, it is still difficult to predict whether the project will be completed by the extended date of completion; i.e., 2015.

The Melamchi River is located about $50 \mathrm{~km}$ North-East of the Kathmandu valley and is one of the tributaries of the Indrawati River. The Indrawati basin is a sub-basin within the Koshi basin (Figure 1). The MWSP diversion points of all stages are situated in the Indrawati River Basin which has a catchment area of $1,228 \mathrm{~km}^{2}$. Melamchi, Yangri and Larke Rivers are major tributaries of the Indrawati River and have about 323,117 and $116 \mathrm{~km}^{2}$ catchment area respectively. The project plans to divert 170 MLD (1.97 $\mathrm{m}^{3} / \mathrm{s}$ ) of water from Melamchi river in Stage-I and an additional 170 MLD each from Yangri and Larke tributaries of the Indrawati River in Stage-II and III (Bhattarai, Pant et al 2002; Mishra and Shilpakar 2001). The project is important and has attracted a lot of attention and interest not only because it is seen as a solution to the drinking water crisis in Kathmandu but also because this is interbasin water transfer project that is in the process of being implemented in Nepal.

At present, the available water in the Melamchi river basin is being used for irrigation, drinking water supply and sanitation, consumption for forest and vegetation, micro-hydropower generation and water mills (MWSDB 2008). The project has a high level of skepticism among the local community and stakeholders, despite the project compensation package as well as the inclusion of minimum flows of $34.56 \mathrm{MLD}\left(0.4 \mathrm{~m}^{3} / \mathrm{s}\right)$ to be released downstream of the diversion (Bhattarai, Pant et al 2002; IUCN 1999; MWSDB 2008). So far, the project has paid about NRs. 880 million to the local community living in project affected areas as cash compensation (MWSDB 2008) and recent project document has reported that project has spent NRs. 900 million till 2011. The demand and grievances of local people plus political circumstances and challenges in engaging the private sector partner have all contributed to delay the completion of the project (Khadka and Khanal 2008).

Although the insufficiency of the prescribed minimum flow releases is one of the main critiques of the project, the few studies that have been carried out to look at water accounting have only focused on the Indrawati River basin (Bhattarai, Pant et al 2002; Mishra and Shilpakar 2001; Sharma 2002). Therefore, this study makes use of the hydrological model developed for the entire Koshi basin to look at the hydrological impacts of the MWSP until the outlet of the Koshi basin at Chatara (Figure 1) under current and future climate change projections. Furthermore, the impact of water transfers on the crop water requirement within the Melamchi River command area was also evaluated. 


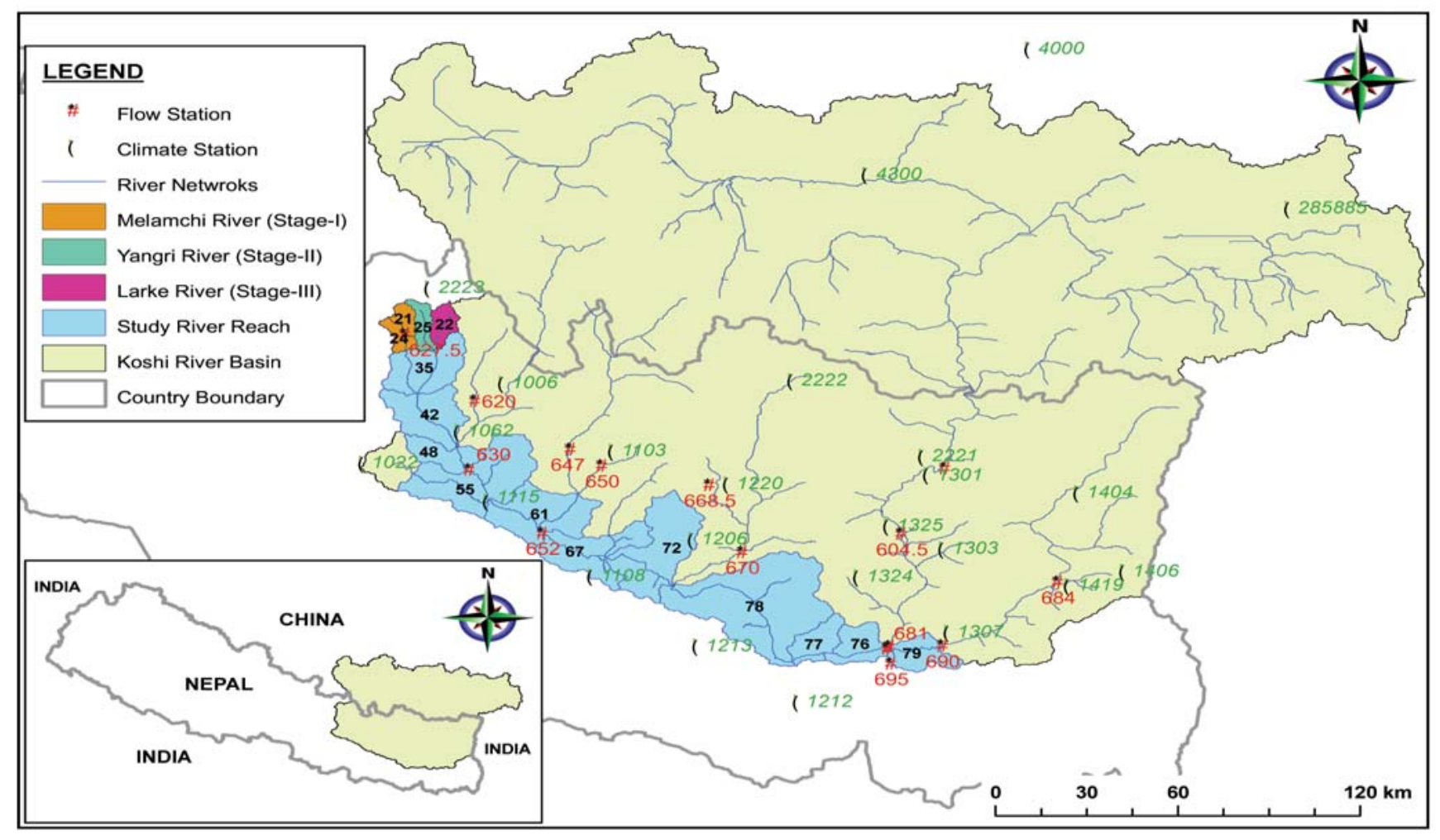

Figure 1. The Study Basin and Observed Climate and Flow Stations.

\section{Data and Method \\ Quantification of water availability}

The Soil and Water Assessment Tool (SWAT) model was setup for the Koshi basin as a part of the Indo-Ganges Basin Focal project (www.slideshare.net/cpwfbfp/indogangesbasin-focal-project). SWAT is a continuous, physically based, semi-distributed hydrological public domain model jointly developed by USDA Agricultural Research Service (USDA-ARS) and Texas AgriLife Research, part of Texas A\&M University System. SWAT is a river basin-scale model to quantify impact of land management practices on water quantity, sediment and water quality in large complex watersheds with varying soils, land use and management conditions over a long period of time (Arnold, Srinivasan et al 1998; Bharati, Pant et al 2011; Neitsch, Arnold et al 2005). For this study, the Koshi basin is divided into 79 sub-basins and delineated with the basin outlet at ChataraKothu. Detailed description of the methodology as well as results from the water balance analysis of the whole Koshi basin is in preparation. Therefore, in this paper, only the results related to the downstream impacts of the MWSP will be discussed.

\section{Simulation of Crop Water Requirement (CWR)}

BUDGET (soil, water and salt balance) model was used to simulate net crop water requirement for agricultural command area of the Melamchi River. BUDGET is a field based model developed by faculty of applied bioscience and engineering, Katholieke Universiteit of Leuven, Belgium. BUDGET requires length and crop coefficient $\left(\mathrm{K}_{\mathrm{c}}\right)$ for the four growth stages: initial, crop development, mid-season and lateseason stage(Shrestha, Geerts etal 2010). Reference evapo-transpiration ( $\mathrm{E} \mathrm{T}_{\mathrm{o}}$ ), rainfall, crop parameters and soil type are essential parameters to evaluate net irrigation requirement (NIR). In this study, $80 \%$ dependable rainfall $\left(R_{m}-0.8429 \times S_{D}\right)$ is taken to evaluate NIR, where $R_{m}$ is mean rainfall and $S_{D}$ is standard deviation. Likewise, $\mathrm{ET}_{\mathrm{o}}$ is evaluated from climate data (temperature, wind speed, sunshine hour and vapor pressure) using New LocClim (local climate estimator) developed by FAO in 2005. Henceforth, comparison between gross irrigation requirement (GIR) and water available in the stream was done in different scenarios.

\section{Downscaled climate data}

In this study, MarkSim weather generator was used to downscale climate data from Global Circulation Model (GCM) (gismap.ciat.cgiar.org/MarkSimGCM/) (Jones, Thornton et al 2002). GCMs used to generate daily climate data are CNRM-CM3, CSIRO-Mk3.5, ECHam5, and $\mathrm{MIROC}_{3} .2$ and the projected data are average of these four GCMs. In addition, statistical downscaled daily climate data is also used in this study. Scenarios families of the Special Report on Emissions Scenarios (SRES), period of projection and climate variables considered in this study are presented in Table 1 . Therefore, five projected scenarios in total (two from MarkSim and three from statistical) are considered to simulate future water availability. Future projected climate data from MarkSim downscaled techniques are $\mathrm{A} 2$ and $\mathrm{B} 1$; and from Statistical downscaled techniques are $\mathrm{A} 1 \mathrm{~B}, \mathrm{~A} 2$ and $\mathrm{B} 1$ of the SRES families. In the study, period of future simulation are 2030 s (average from 2016 to 2045) and 2050s (average from 2036 to 2065), whereas period of base line (BL) is 2000s (from 1971 to 2000).

\section{The Melamchi Water Supply Project (MWSP)}

The downstream impact study is carried out for 11 


\begin{tabular}{|l|l|l|}
\hline \multicolumn{1}{|c|}{ GCMs Downscaled } & Statistical Downscaled \\
\hline SRES families & $\mathrm{BL}, \mathrm{A} 2$ and $\mathrm{B} 1$ & $\mathrm{BL}, \mathrm{A} 1 \mathrm{~B}, \mathrm{~A} 2$ and $\mathrm{B} 1$ \\
\hline $\begin{array}{l}\text { Period of } \\
\text { projection }\end{array}$ & $\begin{array}{l}\text { 2000s (1971-2000) for BL } \\
\text { 2030s (2016-2045) for A2 and B1 } \\
\text { 2050s (2036-2065) for A2 and B1 }\end{array}$ & $\begin{array}{l}(2001-2100) \text { for } \mathrm{BL} \\
\mathrm{(21} \mathrm{B}, \mathrm{A} 2 \text { and B1 }\end{array}$ \\
\hline Climate variable & $\begin{array}{l}\text { Rainfall, Temperature (Max and Min), Solar } \\
\text { Radiation }\end{array}$ & $\begin{array}{l}\text { Rainfall, Temperature (Max and Min), Solar } \\
\text { Radiation, Relative Humidity and Wind Speed }\end{array}$ \\
\hline
\end{tabular}

Table 1. SRES Families and Projection Period of Downscaled Climate Data.

among 79 sub-basins of the Koshi basin. The sequential order of 15 sub-basins and sub-basin numbers are in Figure 2. The study river reach starts from sub-basin 35 and ends at sub-basin 79. The Indrawati, Sun Koshi, Rosi, Tama Koshi, Likhu, Dudh Koshi, Arun and Tamor Rivers flows into the main river reach (Figure 2). The location of water transfer in Stages I, II and III are at the outlet of sub-basins 24 in Melamchi, 25 in Yangri and 22 in Larke rivers respectively (Figure 2). In Stage-I, the calibrated model is re-run by setting planned monthly water transfer in sub-basin 24 by using the water use option in the SWAT model. The model is then re-run according to the monthly water transfer plan from sub-basins 25 and 22 respectively in Stages II and III. three water transfer locations. The study result show that downstream flow availability at the driest month will be approximately more than $13 \%$ of the river flow of that month. The total available annual simulated water is $499 \mathrm{MCM}, 443 \mathrm{MCM}$ and $448 \mathrm{MCM}$ respectively in Melamchi, Yangri and Larke river sub-basins (Table 2). The flow volume of $401 \mathrm{MCM}, 348 \mathrm{MCM}$ and $355 \mathrm{MCM}$ occurred within five monsoonal months (June to October). Therefore, seasonal water flow varies significantly in the rivers and more than $80 \%$ of the total annual flow occurred within these monsoonal months. Hence in the study, June to October is considered as wet season and the other seven months are dry season.

\section{Downstream impact on reaches of Koshi Basin in}

\section{Result and Discussion Water availability in headwork of MWSP in current climate scenario}

As explained above, the outlets of sub-basins number 24, 25 and 22 are the locations for MWSP's water transfer sites in Stages I, II and III respectively. The effective catchment areas of these three transfer stages are 148,110 and $114 \mathrm{~km}^{2}$ respectively. Figure 3 represents flow duration curves and monthly flow volume at the

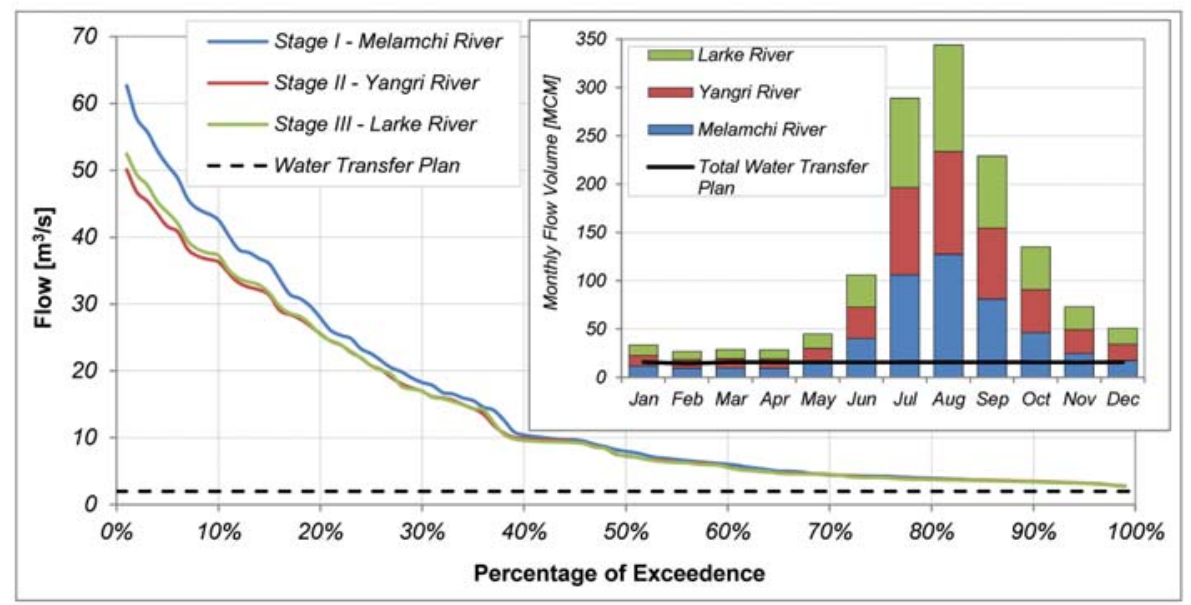

Figure 3. Flow Duration Curve and Monthly Flow Volumes Derived from Simulated Monthly Flows at all three stages of the MIWTP in Current Climate Scenario.
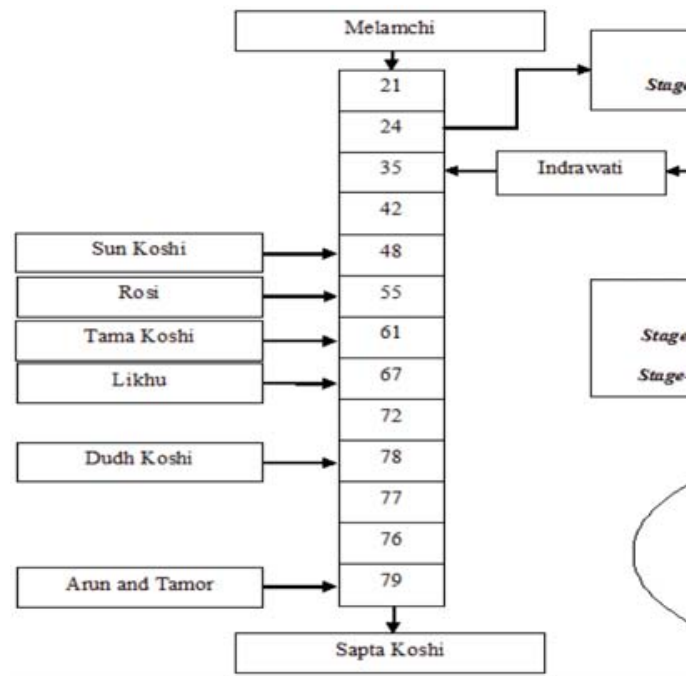

Water Transfer

ge-I: $1.97 \mathrm{~m}^{3} / \mathrm{s}$ [62.1 MCM]

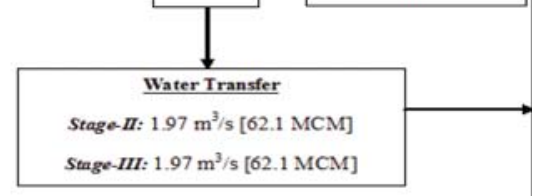

Stage-III: $1.97 \mathrm{~m}^{3} / \mathrm{s}[62.1 \mathrm{MCM}]$

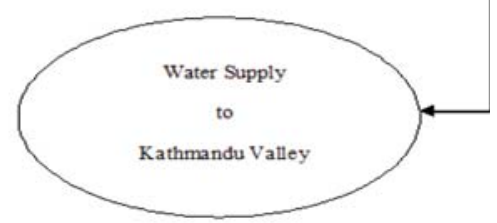

Figure 2. Melamchi Inter-basin Water Transfer Plan and Flow Network in the Koshi Basin (The numbers in the figure refer to sub-basin numbers, which can also be seen in Figure 1).

\section{current climate scenario}

The three rivers Melamchi, Yangri and Larke meet at sub-basin 35 . Therefore, water transfer in all stages will influence sub-basin 35 as well as the downstream sub-basins. Figure 4 shows the comparison of annual and seasonal average water flow. Reduction in flows will occur in sub-basin 24 after Stage-I and subsequently it will occur in subbasin 25 and 22 after Stages II and III. Once the MWSP becomes operational, the annual average discharges flowing into sub-basin 35 will reduce by $12 \%, 14 \%$ and $14 \%$ due to the water transfer plan of Stages I, II and III respectively (Figure 4). Likewise, in the Koshi basin outlet, at Chatara-Kothu, cumulative effects of all water transfer Stages (I, II and III) on 


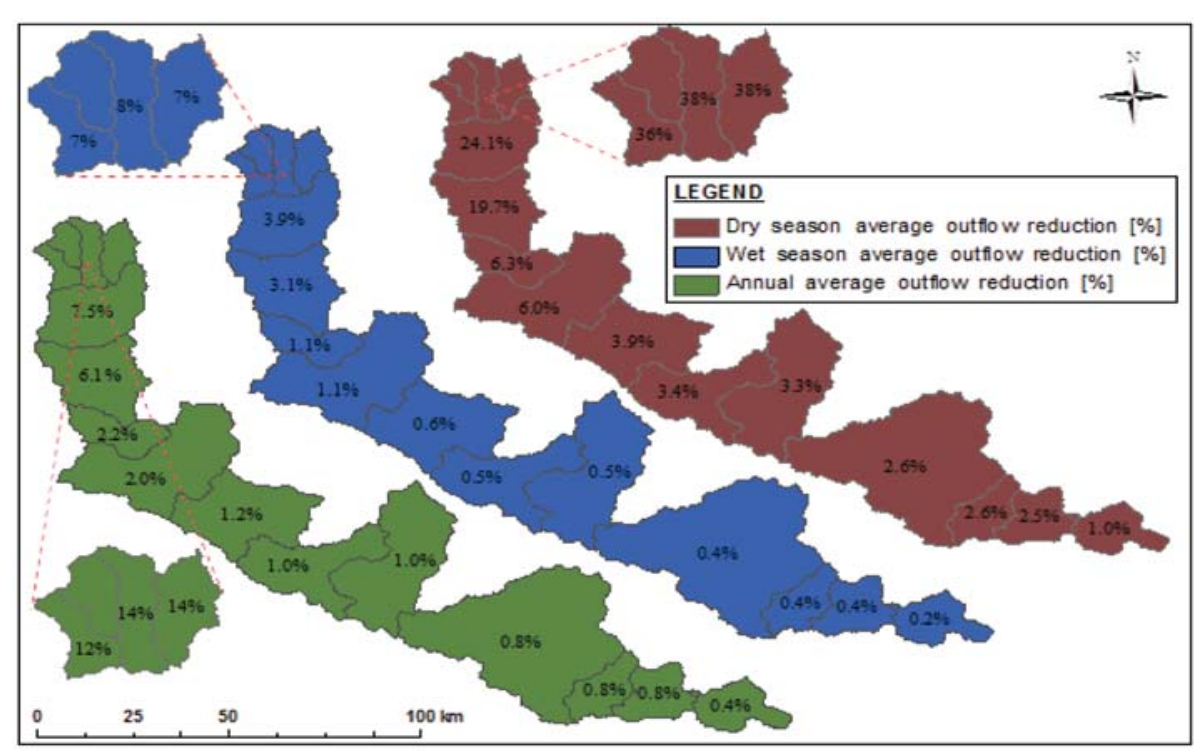

Figure 4. Percent Flow Reduction Due to MIWTP in Affected Sub-basins for Annual, Dry Season (Nov-May) and Wet Season (Jun-Oct).

annual average flow is $0.4 \%$. Seasonal results show that in the Stage-I water transfer plan, average inflow reduction in sub-basin 35 in the dry and wet seasons are $36 \%$ and $7 \%$ respectively, whereas in Stage-II the inflow reduction are $38 \%$ for the dry season and $8 \%$ for the wet season. In Stage-III, flow reductions are $38 \%$ in the dry season and $7 \%$ in the wet season (Figure 4). Furthermore, in the Koshi basin outlet, at Chatara-Kothu, cumulative effects of all water transfer stages (I, II and III) on average flow reduction in the dry and wet seasons are 1.0\% and $0.2 \%$ respectively.

\section{Water availability in headwork of MWSP in future climate scenarios}

The annual simulated flow under the current climate and the range of projected flows under climate change scenarios are presented in Table 2. The water availability ranges and means of projected flows as shown in Table 2 represent the results from five projected future climate scenarios (two from MarkSim and three from statistical downscaled data) for $\mathrm{A} 2, \mathrm{~B} 1$ and $\mathrm{A} 1 \mathrm{~B}$ scenarios. Results show that on an average, flows in the rivers will decrease in the projection period of 2030 s and 2050 s when compared to the current flows.

\begin{tabular}{|l|c|c|c|}
\hline & $\begin{array}{c}\text { Current flow } \\
\text { (MCM) }\end{array}$ & \multicolumn{2}{|c|}{$\begin{array}{c}\text { Range and Mean of projected } \\
\text { flow (MCM) }\end{array}$} \\
\cline { 2 - 4 } & $\mathbf{( 1 9 7 6 - 2 0 0 5 )}$ & 2030s & 2050s \\
\hline Before MWSP: & & & \\
\hline Melamchi river & 499 & $312-347(333)$ & $316-359(340)$ \\
\hline Yangri river & 443 & $306-336(324)$ & $306-340(325)$ \\
\hline Larke river & 448 & $302-342(323)$ & $299-349(322)$ \\
\hline After MWSP: & & & \\
\hline Melamchi river & 437 & $250-285(271)$ & $254-297(278)$ \\
\hline Yangri river & 381 & $244-274(262)$ & $244-278(263)$ \\
\hline Larke river & 386 & $240-280(261)$ & $237-287(260)$ \\
\hline
\end{tabular}

Table 2. Range of Change on Annual Water Availability in Future Climate Change Scenario.

\section{Downstream impact on reaches of Koshi Basin in future climate scenarios}

Figure 5 illustrates change in water availability in the subbasins falling within the MWSP sub-basins under future climate change projections from 2030 s and 2050s under SRES scenario A2 (downscaled using Marksim). Results of future projection in 2030s (Figure 5 (a)) show that annual flow in the Melamchi, Yangri and Larke rivers will change by $+1 \%,+2 \%$ and $+2 \%$ respectively than the current flows, whereas the wet season flow will change by $-1 \%, 0 \%$ and $+2 \%$ and dry season flow by $+5 \%,+10 \%$ and $+2 \%$ respectively. Similarly, in 2050s (Figure 5 (b)), the annual

flow in the Melamchi, Yangri and Larke rivers will change by $+3 \%,+4 \%$ and $+5 \%$ than the current flows, whereas the wet season flow will change by $+2 \%,+2 \%$ and $+6 \%$ and dry
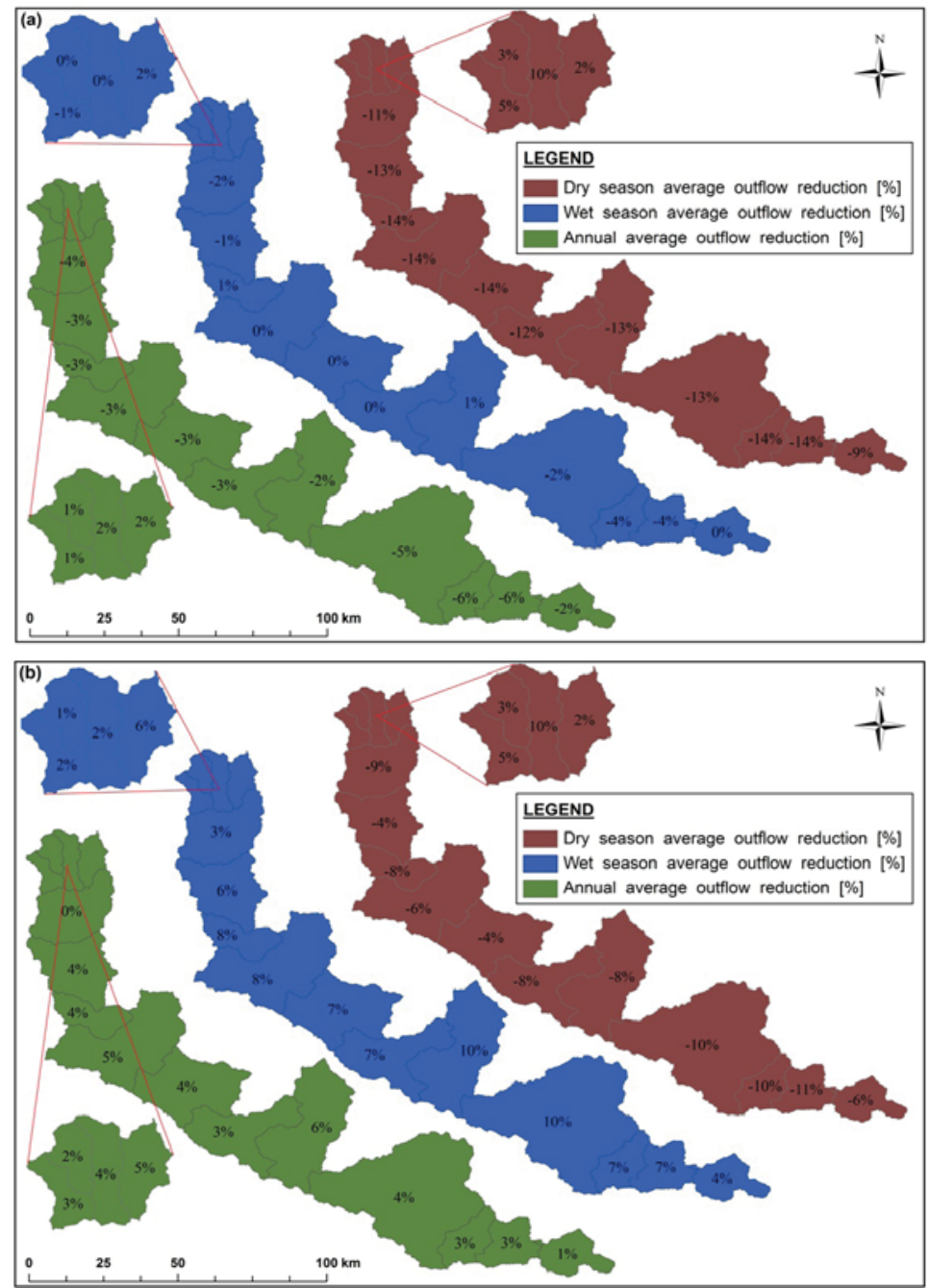

Figure 5. Percentage Change of Projected Flow in Affected Sub-basins for Annual, Dry Season (Nov-May) and Wet Season (Jun-Oct), (a) in 2030s and (b) in 2050s; under Climate Change Projection Scenario of Marksim-A2. 


\begin{tabular}{|c|c|c|c|c|c|c|c|c|c|c|c|c|c|c|}
\hline Crop & Irrigated & Cropping & Jan & Feb & Mar & Apr & May & Jun & Jul & Aug & Sep & Oct & Nov & Dec \\
\hline type & area (ha) & duration (day) & \begin{tabular}{l|l|}
1 & 2 \\
\end{tabular} & \begin{tabular}{l|l}
1 & 2 \\
\end{tabular} & \begin{tabular}{l|l}
1 & 2 \\
\end{tabular} & \begin{tabular}{l|l}
1 & 2 \\
\end{tabular} & \begin{tabular}{|l|l|}
1 & 2 \\
\end{tabular} & \begin{tabular}{|l|l|}
1 & 2 \\
\end{tabular} & $\begin{array}{ll}1 & 2 \\
\end{array}$ & \begin{tabular}{l|l}
1 & 2 \\
\end{tabular} & \begin{tabular}{l|l}
1 & 2 \\
\end{tabular} & \begin{tabular}{l|l}
1 & 2 \\
\end{tabular} & \begin{tabular}{l|l}
1 & 2 \\
\end{tabular} & \begin{tabular}{l|l}
1 & 2 \\
\end{tabular} \\
\hline Paddy & 101 & 150 & & & & & & & & & & & $2 \pi$ & \\
\hline Wheat & 74 & 135 & & & 30 & & & & & & & & 16 & \\
\hline Maize & 289 & 125 & & & & & & & & $3^{3}$ & & & & \\
\hline Millet & 188 & 105 & & & & & & 16 & & & 20 & & & \\
\hline Barley & 4 & 120 & & & 10 & & & & & & & & $\infty$ & \\
\hline Pulses & 47 & 100 & & & 23. & & & & & & & & & 10 \\
\hline Oilseed & 52 & 110 & & & & + & & & & & & & & 16 \\
\hline Potato & 62 & 130 & & & & $\circ$ & & & & & & & & 1 \\
\hline Vegetable & 50 & 105 & & 22 & & & & & & & & & 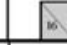 & \\
\hline Crop & Irrigated & Cropping & Jan & Feb & Mar & Apr & May & Jun & Jul & Aug & Sep & Oct & Nov & Dec \\
\hline type & & duration (day) & \begin{tabular}{|l|l|}
1 & 2 \\
\end{tabular} & \begin{tabular}{|l|l|}
1 & 2 \\
\end{tabular} & \begin{tabular}{|l|l|}
1 & 2 \\
\end{tabular} & \begin{tabular}{|l|l|}
1 & 2 \\
\end{tabular} & \begin{tabular}{|l|l|}
1 & 2 \\
\end{tabular} & \begin{tabular}{l|l}
1 & 2 \\
\end{tabular} & \begin{tabular}{|l|l|}
1 & 2 \\
\end{tabular} & \begin{tabular}{|l|l|}
1 & 2 \\
\end{tabular} & \begin{tabular}{|l|l|}
1 & 2 \\
\end{tabular} & \begin{tabular}{l|l}
1 & 2 \\
\end{tabular} & \begin{tabular}{|l|l|}
1 & 2 \\
\end{tabular} & \begin{tabular}{|l|l|}
1 & 2 \\
\end{tabular} \\
\hline Early padd & 16 & 90 & & & 23 & & & $=2$ & & & & & & \\
\hline Main paddy & 289 & 105 & & & & & & 23 & & & & 7 & & \\
\hline Wheat & 74 & 120 & & & 15 & & & & & & & & roo & \\
\hline Maize & 128 & 105 & & & 1 & & & $D$ & & & & & & \\
\hline Vegetable & 215 & 180 & & & & 8 & & & & & & in & & \\
\hline
\end{tabular}

Table 3. Existing Cropping Pattern and Crop Calendar of the Melamchi River Command Area (top) and the Cropping Pattern Recommended by Department of Irrigation (DOI) (bottom) Scenario. pattern as well as the recommended cropping pattern scenarios. Figure 6 shows that irrigation is only required in the dry season. In the existing cropping pattern scenario, intensive irrigation is required in April (130 $\mathrm{mm})$. In the recommended cropping pattern, irrigation is required in March (158 mm).

Results show that the water scarcity is only during the dry season. Figure 7 shows that water for irrigation is sufficient in driest month even after implementation of MWSP. Other water uses such as drinking water and operating water mills are not accounted in this study. These demands season flow by $+5 \%,+10 \%$ and $+2 \%$ respectively. Likewise, in the Koshi basin outlet, at Chatara-Kothu, annual outflow will change by $-2 \%$ in 2030 s and $+1 \%$ in 2050 s climate change projection. Similarly, wet season outflow from Koshi basin will change by $-9 \%$ in 2030 s and $-6 \%$ in 2050s, whereas dry season outflow will reduce by $21 \%$ in 2030 s and $19 \%$ in 2050 s climate change projections.

\section{Impact on agricultural command area of Melamchi River in current and future scenario}

According to simulation results, MIWTP will not have considerable impact on the hydrology of downstream subbasins except in immediate sub-basins 35 and 42 (Figure 4). After implementation of the project, dry season flows (Nov-May) will drop by $24.1 \%$ and $19.7 \%$ in sub-basins 35 and 42 respectively. Therefore, in this study only impact of Stage-I water transfer plan on the exiting irrigation system in Melamchi River basin is evaluated. At present, nearly 289 hectares (MWSDB 2008) of downstream agricultural lands are irrigating from Melamchi River.

The cropping pattern, area and calendar were used to evaluate crop water requirement in the agricultural command area of the Melamchi River (Table 3). The existing cropping pattern in the study area was identified through farmer discussions, statistical information on Nepalese Agriculture (2005). The recommend cropping patterns are from the Department of Irrigation for the Melamchi command area. The crop characteristics and crop duration are taken from Raes (2002) and McDonald (1990). For simulation, initial soil water content is considered to be $50 \%$ of Total Available Water (TAW), where TAW is difference between field capacity and wilting point.

Figure 6 illustrates simulated monthly Crop Water Requirement (CWR) for the existing cropping do not have considerable impact on irrigation systems because spring sources (ground water) are used for drinking purposes and water used in mills is immediately returned to the river (MWSDB 2008). In addition, tributaries of Melamchi River are adding more water to the river before the confluence of Indrawati river (MWSDB 2008).

Figure 8 depicts comparative scenarios of gross irrigation requirement with $40 \%$ overall irrigation efficiency and change in Melamchi River command area. The plots are demand versus supply curves. Each plot represent water use in four scenarios; (i) existing cropping pattern before operation of MWSP, (ii) existing cropping pattern after operation of MWSP, (iii) recommended cropping pattern before operation of MWSP, and (iv) recommended cropping pattern after operation of MWSP. Under the recommended cropping pattern, results show that the present Melamchi River command area can be increased by $120 \%$ under current climate scenarios (Figure $8(\mathrm{a})$ ), whereas the area can be increased by $40 \%$ in $2030 \mathrm{~s}$ (Figure $8(\mathrm{~b})$ )and by $97 \%$ in 2050 s climate projection scenarios (Figure 8(c)).

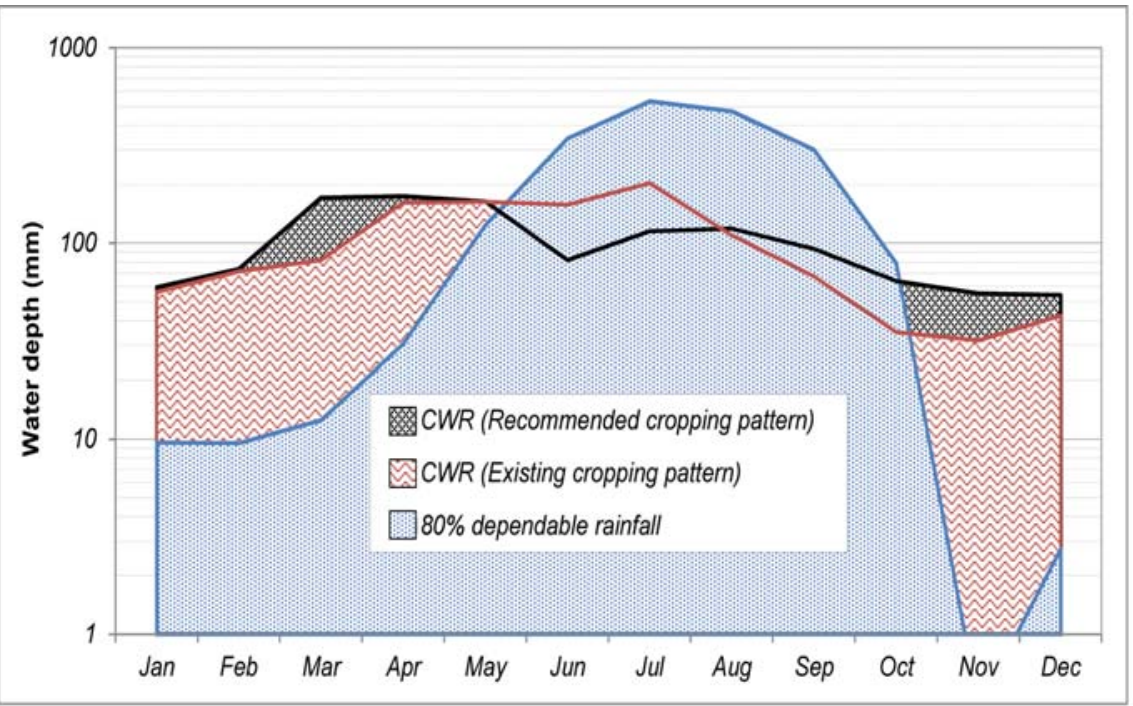

Figure 6. Comparison of $80 \%$ Dependable Rainfall and Monthly Crop Water Requirement for Crops in Melamchi River Command Area. 


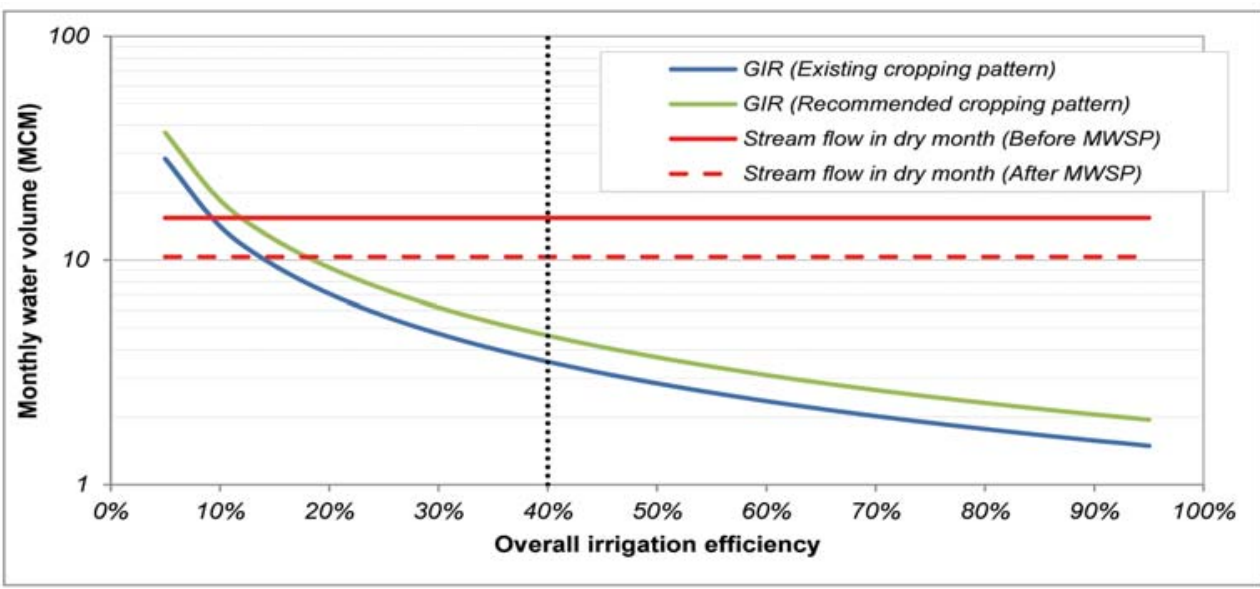

Figure 7. Comparison between Gross Irrigation Requirement and Stream Flow in April.
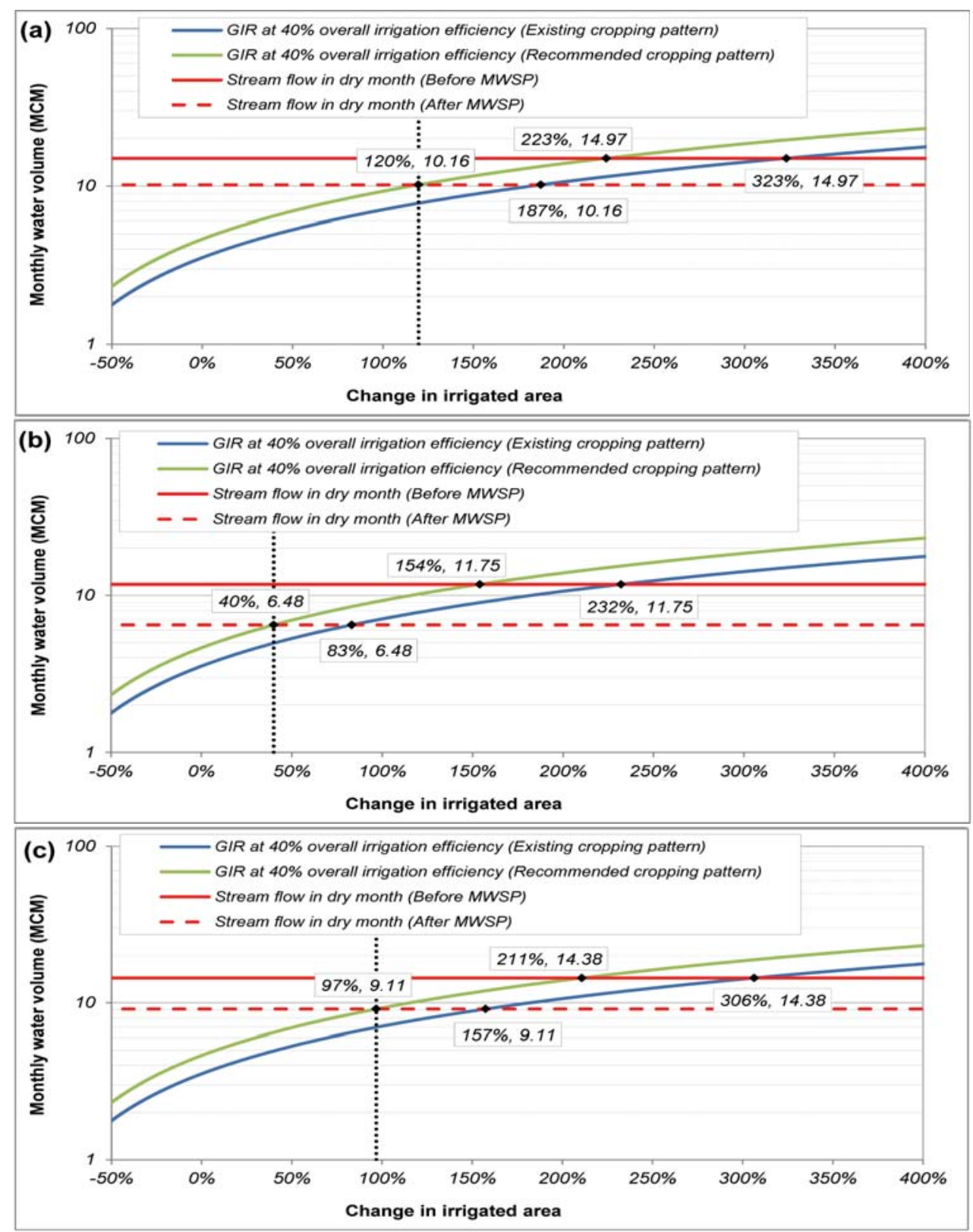

Figure 8. Comparison between Gross Irrigation Requirement and Stream Flow in the Driest Month (April) with Change in the Melamchi River Command Area under (a) Current Climate Scenario, (b) Future Climate Scenario in 2030s, and (c) Future Climate Scenario in 2050s.

\section{Conclusion}

Although the debate on downstream hydrological impacts of the MIWTP is affecting the progress of the project, detailed quantification of the impacts in downstream sub-basins have not been done. Therefore, this paper serves to fill this gap. The simulated results show that in the Stage-I water transfer plan, average inflow reduction in sub-basin 35 in the dry and wet seasons are $36 \%$ and $7 \%$ respectively, whereas in Stage-II the inflow reduction are $38 \%$ for the dry season and $8 \%$ for the wet season. In Stage-III, inflow reductions are $38 \%$ in the dry season and $7 \%$ in the wet season. Furthermore, in the Koshi basin outlet, at Chatara-Kothu, cumulative effects of all water transfer Stages (I, II and III) on average outflow reduction in the dry and wet seasons are $1.0 \%$ and $0.2 \%$ respectively. Therefore, MIWTP has considerable hydrological impacts on the subbasin that is immediately downstream of the transfer points but not further downstream towards the basin outlet.

Simulation results of crop water requirements show that water stress problem will not occur in the Melamchi River command area under current and future climate scenarios, if the command area remains the same as present. Furthermore, by changing the cropping pattern to the recommended cropping pattern from DOI, present Melamchi River command area can be increased by 2.2 times under the current climate scenario, by 1.4 times under climate change projections from 2030s and by 2.0 times under climate change projections from 2050s. As water availability is only a constraint during 
dry months, if in system water storage methods are introduced to reserve excess water of the wet season, the command area can be further increased. In this case, the available of cultivable land might be the constraining factor.

Pabitra Gurung, MSc, Research Officer, International Water Management Institute, IWMI-Nepal. Mr. Gurung has over six years working experience in the field of water resources. He has a Bachelor degree in civil engineering from Tribhuvan University, Nepal and a Master Degree in Water Resources Engineering degree from Katholieke Universiteit Leuven, Belgium. He has worked in projects in Nepal, India and Belgium. His key area of interest and expertise are: hydrological analysis and modeling, crop water modeling, hydraulic design and climate change impact studies on water resources.

Corresponding address: P.Gurung@CGIAR.ORG

Luna Bharati, PhD, has over 15 years of experience in projects related to natural resources and land and water management. She has a Masters in Water Resources and a Doctorate from the Faculty of Agriculture focusing on surface hydrology, erosion and pollutant transport. She has worked in projects in Nepal, USA, Germany, India, Bangladesh, China, Ghana and Burkina Faso. The key areas of her interests and expertise are in: Field investigation and modeling of erosion and nutrient transport and the impacts on water quality (models used: AGNPS, Erosion 3D), Modeling the water balance of a catchment and the influence of climate and land use change using distributed watershed models (e.g.,WaSimETH, SWAT, GeoSFM, WEAP), Developing integrated environmental and economic models for calculating optimal water use and allocation for decision support systems, Calculating environmental flow requirements in the context of basin water allocation strategies. Currently, Dr. Bharati is a Senior Researcher in Hydrology and Water Resources and the Head of the International Water Management Institute (IWMI)-Nepal office.

Corresponding Address: l.bharati@cgiar.org.

\section{Reference}

Arnold, J.G., R. Srinivasan, R.S. Muttiah and J.R. Williams, 1998, 'Large area hydrologic modeling and assessment, Part I: Model development', Journal of the American Water Resources Association 34(1):73-89.

Bharati, L., G. Lacombe, P. Gurung, P. Jayakody, C.T. Hoanh and V. Smakhtin, 2011, The Impacts of Water Infrastructure and Climate Change on the Hydrology of the Upper Ganges River Basin, IWMI Research Report 142, Colombo, Sri Lanka: International Water Management Institute. URL: doi: 10.5337/2011.210.

Bhattarai, M., D. Pant, V.S. Mishra, H. Devkota, S. Pun, R.N. Kayastha and D. Molden, 2002, Integrated Development and Management of Water Resources for Productive and Equitable Use in the Indrawati River Basin, Nepal, Working Paper 41, Colombo, Sri Lanka: International Water Management Institute.
IUCN, 1999, Environmental Impact Assessment (EIA) of Melamchi Water Supply Project, Kathmandu: IUCN (World Conservation Union) in association with METCON for the Melamchi Water Supply Development Board, Government of Nepal.

Jones, P.G., P.K. Thornton, W. Diaz, P.W. Wilkens, and A.L. Jones, 2002, MarkSim-A Computer Tool That Generates Simulated Weather Data for Crop Modeling and Risk Assessment (Version 1), Cali, Colombia: International Center for Tropical Agriculture (CIAT).

Khadka, R.B. and A.B. Khanal, 2008, 'Environmental Management Plan (EMP) for Melamchi Water Supply Project, Nepal', Environmental Monitoring and Assessment, Earth and Environmental Science 146(13):225-234.

MacDonald, M. and Partners Ltd., 1990. Hydrology and Agro-metrology Manual, M3, Design Manuals for Irrigation Projects in Nepal, Kathmandu: Department of Irrigation.

MWSDB, 2008, Work Plan and Annual Progress Report of Melamchi Water Supply Project (Melamchi Project Document), Kathmandu: Melamchi Water Supply Development Board, Government of Nepal.

Mishra, V.S. and R.L. Shilpakar, 2001, 'Water Accounting for Indrawati River Basin, Nepal', a paper presented at the workshop on 'Integrated Development and Management of Nepal's Water Resources for Productive and Equitable Use', Kathmandu, organized by the Nepal Water and Energy Commission Secretariat (WECS/Government of Nepal) and the International Water Management Institute (IWMI) Nepal.

CBS, 2011, National Population Census 2011: Preliminary Result on National Population and Housing Census, Kathmandu: Central Bureau of Statistics and National Planning Commission Secretariat, Government of Nepal

Neitsch, S.L., J.G. Arnold, J.R. Kiniry and J.R. Williams, 2005, Soil and Water Assessment Tool Theoretical Documentation, Temple, TX, USA: Grassland, Soil and Water Research Laboratory, Agricultural Research Service, and Blackland Research Center, Texas Agricultural Experiment Station.

Raes, D., 2002, Reference Manual of BUDGET: A Soil Water and Salt Balance Model (Version 5.0), Leuven, Belgium: Faculty of Agricultural and Applied Biological Sciences, Institute for Land and Water Management, Katholieke Universiteit.

Sharma, C., 2002, 'Effect of Melamchi Water Supply Project on Soil and water conservation in the Indrawati River Basin, Nepal', in Proceedings of the 12th ISCO Conference, Beijing, 'Sustainable Utilization of Global Soil and Water Resources', organized by the Ministry of Water Resources, People's Republic of China.

Shrestha, N., S. Geerts, D. Raes, S. Horemans, S. Soentjens, F. Maupas and P. Clouet, 2010, 'Yield response of sugar beets to water stress under Western European conditions', Agricultural Water Management 97(2):346-350. 